\title{
Potential Role of Sequential Glufosinate and Foramsulfuron Applications for Management of Fescues (Festuca spp.) in Wild Blueberry
}

\author{
Scott N. White and Shanthanu Krishna Kumar*
}

Sheep and hair fescue are perennial, tuft forming grasses that spread by seed and form dense sods in wild blueberry fields. These sods compete with the crop for resources and hinder harvest. Field and greenhouse studies were conducted in 2015 to evaluate 1) the effect of sequential glufosinate and foramsulfuron applications on suppression of fescues in the greenhouse and field, and 2) efficacy of glufosinate and foramsulfuron on fescue seedlings when applied at 2, 4, 6, and $8 \mathrm{wk}$ after seedling emergence in the greenhouse. Glufosinate applications at 750 and $1,005 \mathrm{gai} \mathrm{ha}^{-1}$ followed by foramsulfuron application at $35 \mathrm{~g}$ ai ha ${ }^{-1}$ reduced fescue leaf number and biomass relative to foramsulfuron application alone in the greenhouse. In the field study, fescue flowering tuft density, tuft inflorescence height, seed production, and seed viability were reduced by foramsulfuron alone, but there was a trend towards lower seed production and tuft height when fescues were treated with glufosinate at $1,005 \mathrm{~g} \mathrm{ha}^{-1}$ followed by foramsulfuron. Foramsulfuron caused low seedling mortality at all application timings evaluated, but glufosinate caused $>90 \%$ mortality in seedlings when applied at 2, 4, 6, or 8 wk after seedling emergence. Our results suggest that sequential applications of these herbicides are less effective under field conditions relative to results obtained in the greenhouse, though burndown glufosinate applications may have a role in reducing fescue seedling recruitment. Additional research should be conducted to determine the effect of early spring and autumn glufosinate applications on fescue seedling recruitment and suppression of established fescue tufts with subsequent foramsulfuron applications.

Nomenclature: Foramsulfuron; glufosinate; sheep fescue; Festuca ovina L. FESOV; hair fescue, Festuca filiformis Pourret FESTE; lowbush blueberry, Vaccinium angustifolium Aiton.

Key words: Perennial crop, perennial grass, burndown herbicide, sequential herbicide.

\begin{abstract}
Festuca ovina y Festuca filiformis son gramíneas perennes que forman espigas, que se son dispersadas por semilla y que forman céspedes densos en campos de arándano silvestre. Estos céspedes compiten con el cultivo por recursos y dificultan la cosecha. En 2015 se realizaron estudios de campo y de invernadero para evaluar 1) el efecto de aplicaciones secuenciales de glufosinate y foramsulfuron sobre la supresión de plántulas de Festuca spp. cuando se aplicaron a 2, 4, 6, y 8 semanas después de la emergencia de las plántulas en el invernadero. Aplicaciones de glufosinate a 750 y $1,005 \mathrm{~g}$ ai ha ${ }^{-1}$ seguidas por una aplicación de foramsulfuron a $35 \mathrm{~g} \mathrm{ai} \mathrm{ha}^{-1}$ redujeron el número de hojas y la biomasa de Festuca spp. en relación con aplicaciones de sólo foramsulfuron en el invernadero. En el estudio de campo, la densidad de inflorescencias, la altura de la inflorescencia, la producción de semilla, y la viabilidad de la semilla fueron reducidas con la aplicación de foramsulfuron solo, pero hubo una tendencia hacia una menor producción de semilla y de altura de inflorescencia cuando Festuca spp. fue tratada con glufosinate a $1,005 \mathrm{~g} \mathrm{ha}^{-1}$ seguido por foramsulfuron. Foramsulfuron causó baja mortalidad de plántulas en todos los momentos de aplicación evaluados, pero glufosinate causó $>90 \%$ de mortalidad en plántulas cuando se aplicó a 2, 4, 6, ó 8 semanas después de la emergencia de plántulas. Nuestros resultados sugieren que las aplicaciones secuenciales de estos herbicidas son menos efectivas en condiciones de campo en relación a los resultados obtenidos en el invernadero, aunque aplicaciones de glufosinate para quema generalizada podrían tener un rol en la reducción de establecimiento de plántulas de Festuca spp. Se debería realizar investigación adicional para determinar el efecto de aplicaciones de glufosinate temprano en la primavera y en el otoño sobre el establecimiento plántulas de Festuca spp. y la supresión de inflorescencias de plantas establecidas Festuca spp. con aplicaciones subsecuentes de foramsulfuron.
\end{abstract}

The wild, or lowbush, blueberry is a native, perennial berry species in Nova Scotia, Canada. Commercial fields are developed on abandoned farmland or cleared woodland where native blueberry stands already exist (AAFC 2005). Stands are managed primarily on a two-year cycle in which fields are

DOI: 10.1614 /WT-D-16-00086.1

*Assistant Professor and Summer Research Assistant, Department of Plant, Food, and Environmental Sciences, Dalhousie University Faculty of Agriculture, Truro, NS, B2N 5E3, Canada. Corresponding author's E-mail: scott.white@dal.ca 
pruned to ground level in the first year (non-bearing year) and harvested in the second year (bearing year) (AAFC 2005). Weed management options are limited due to the perennial nature of the crop, and weeds are therefore a major yield limiting factor (Jensen 1985; McCully et al. 1991). The weed flora of wild blueberry fields is diverse, but several species of perennial grasses have become important weeds since the introduction of hexazinone in the early 1980s (Jensen and Yarborough 2004).

Fescues are common perennial grasses in wild blueberry fields, with sheep and hair fescue among the most common species. Sheep and hair fescue are densely tufted, cool-season grasses, which are native to Europe and were introduced to North America as turfgrass species (Cronquist et al. 1977). These grasses are common throughout Nova Scotia (Munro et al. 2014), reproduce exclusively by seed, and have traditionally been controlled in wild blueberry fields with preemergence applications of herbicides such as hexazinone (Jensen and Kimball 1985; Sampson et al. 1990), atrazine (Jensen 1986; Sampson et al. 1990), and to some extent terbacil (Smagula and Ismail 1981). Fescue abundance in wild blueberry fields in Nova Scotia has increased in recent years, however, due to suspected resistance to traditional herbicides (Anonymous 2015b; Jensen and Specht 2004; Jensen and Yarborough 2004), deregistration of atrazine in wild blueberry, lack of control from registered graminicides such as fluazifop-p-butyl [butyl (2R)-2-(4-[5(trifluoromethyl)pyridin-2-yl] oxyphenoxy)propanoate] and sethoxydim, and secondary dispersal of seeds on harvesting equipment (Boyd and White 2009).

Fescues are currently most effectively managed in wild blueberry with preemergence applications of propyzamide (3,5-dichloro ( $N$-1,1-dimethyl-2propynyl)benzamide). Although effective, the lack of alternative control options limits the long term sustainability of propyzamide as a management tool, as exclusive reliance on this product increases the likelihood of selection for herbicide resistance (Norsworthy et al. 2012). This product is also expensive and difficult to use due to the requirement that applications be made to cold soils in late autumn to prevent volatilization. Foramsulfuron was recently registered for postemergence control of fescues in wild blueberry, but is most effective on young seedlings at the 3 to 6 leaf stage (Anonymous 2015a). Established fescue tufts typical of infestations in wild blueberry fields in Nova Scotia routinely exceed this growth stage, and suppression of established plants with foramsulfuron is therefore variable and treated plants often recover from initial injury (SN White, personal observation). The recent registration of the non-selective burndown herbicide glufosinate in wild blueberry, however, provides the opportunity to reduce fescue tuft leaf number prior to foramsulfuron applications through the use of burndown applications during times of blueberry dormancy. Reduction of excess growth of tall fescue (Lolium arundinaceum (Schreb.) S.J. Darbyshire) with burning, for example, improved efficacy of subsequent postemergence herbicide applications (Washburn et al. 1999). Burn pruning is practiced by some wild blueberry growers, but many growers use flail mowing instead because of its lower production costs (Yarborough 2004). Many growers are therefore interested in the potential role of burndown glufosinate applications in their overall weed management plans, and improved control of perennial grasses, such as fescues, is one possible benefit.

The objectives of this study were 1) to determine the effect of sequential glufosinate and foramsulfuron applications on sheep and hair fescue, and 2) to determine the efficacy of postemergence glufosinate and foramsulfuron applications on fescue seedlings.

\section{Materials and Methods}

\section{Effect of Sequential Glufosinate and Foramsulfuron Applications on Sheep and Hair Fescue. Experi-} ments were conducted in the greenhouse and field to determine the effect of sequential glufosinate (Ignite ${ }^{\circledR}$ SN herbicide, Bayer CropScience, Calgary, $\mathrm{AB}$, Canada) and foramsulfuron (Option ${ }^{\circledR} 2.25 \mathrm{OD}$ herbicide, Bayer CropScience) applications on suppression of sheep and hair fescue. The greenhouse experiment was conducted using sheep and hair fescue plants established from seed obtained from a commercial source and an infested grower field in Salt Springs, Nova Scotia, respectively, and the field experiment was conducted in two grower fields infested with hair fescue. The experiment was a 4 by 2 factorial arrangement of glufosinate application rate $\left(0,405,750\right.$, and $\left.1,005 \mathrm{~g} \mathrm{ai} \mathrm{ha}^{-1}\right)$ and foramsulfuron application $\left(0\right.$ or $\left.35 \mathrm{~g} \mathrm{ai} \mathrm{ha}^{-1}\right)$ in a completely randomized design with 5 replicates in the greenhouse and in a randomized complete block design with 4 blocks in the field. 
For the greenhouse study, five pre-germinated sheep or hair fescue seeds were planted in $3,000 \mathrm{~cm}^{3}$ plastic pots filled with a 1:1:1 (by vol) mixture of sand, potting soil (Pro-Gro ${ }^{\circledR}$ Premium Organic Top Soil, Annapolis Valley Peat Moss Co. Ltd., Berwick, NS), and peat. Plants were maintained under a 16-h photoperiod consisting of daylight extended to $16 \mathrm{~h}$ by metal halide lamps providing a photosynthetic photon flux density of $61 \pm 3 \mu \mathrm{mol} \mathrm{m} \mathrm{m}^{-2} \mathrm{~s}^{-1}$ at plant level. Mean temperature in the greenhouse during the experiment was $22 \pm 0.1 \mathrm{C}$. Pots were watered as needed, and were re-randomized and fertilized with a $0.12 \%$ solution of $20-20-20$ (N-P-K) general fertilizer blend (Home Gardener ${ }^{\circledR}$, Home Hardware Stores Ltd., St. Jacobs, ON) every 2 wk at a rate of $100 \mathrm{~mL}$ fertilizer solution per pot. Initial glufosinate applications, as well as the foramsulfuron application made without an initial glufosinate application, were made at 63 and $90 \mathrm{~d}$ after planting (DAP) for sheep and hair fescue, respectively, and foramsulfuron was applied to fescue regrowth in the appropriate treatments 1 mo after the initial herbicide applications. Herbicides were applied using a hand-held, $\mathrm{CO}_{2}$-pressurized single nozzle sprayer outfitted with a Teejet ${ }^{\circledR}$ XR 11002 nozzle and calibrated to deliver a water volume of $200 \mathrm{~L} \mathrm{ha}^{-1}$ at a pressure of $207 \mathrm{KPa}$. Data collection included sheep fescue leaf counts at $0,30,45$, and $60 \mathrm{~d}$ after initial herbicide applications (corresponding with 63, 93, 112, and 123 DAP), hair fescue leaf counts at 0,30 , and $60 \mathrm{~d}$ after initial herbicide applications (corresponding with 90, 120, and $150 \mathrm{DAP}$ ), and final aboveground sheep fescue biomass in each pot at the end of the experiment. Biomass data were not collected for hair fescue. For sheep fescue biomass measurements, all aboveground plant material was clipped to soil level in each pot. Dead leaves, and leaves exhibiting more than $75 \%$ necrosis, were removed, and remaining plant material was placed in paper bags and dried at $70 \mathrm{C}$ for $48 \mathrm{~h}$ prior to weighing. The experiment was repeated once for each species.

The field experiment was conducted in two nonbearing year commercial wild blueberry fields located at Salt Springs $\left(45^{\circ} 52^{\prime} 64^{\prime \prime} \mathrm{N}, 62^{\circ} 92^{\prime} 07^{\prime \prime} \mathrm{W}\right)$ and Sherbrooke $\left(45^{\circ} 23^{\prime} 60^{\prime \prime} \mathrm{N}, 62^{\circ} 17^{\prime} 15^{\prime \prime} \mathrm{W}\right)$, Nova Scotia. Plot size was $2 \mathrm{~m}$ wide by $6 \mathrm{~m}$ long, with $1-\mathrm{m}$ buffer strips between blocks. Initial glufosinate applications, as well as the foramsulfuron application made without an initial glufosinate application, were made on May 18, 2015. Subsequent foramsulfuron applications were made to appropriate treatments on June 04, 2015. Herbicide applications were made using a $\mathrm{CO}_{2}$-pressurized research plot sprayer outfitted with four Teejet ${ }^{\circledR}$ XR 11002 nozzles calibrated to deliver a water volume of $200 \mathrm{~L} \mathrm{ha}^{-1}$ at a pressure of $207 \mathrm{KPa}$. Data collection included living fescue tuft density at 0,30 , and $60 \mathrm{~d}$ after initial herbicide applications; flowering fescue tuft density at $60 \mathrm{~d}$ after initial herbicide applications; and flowering fescue tuft inflorescence number, inflorescence height, seed production, and seed viability; and blueberry stem density, stem height, and flower bud number per stem. Living and flowering tuft counts were conducted in two $1-\mathrm{m}^{-2}$ quadrats in each plot, and the mean of the two counts was used in the analysis. Tuft inflorescence number and inflorescence height were determined on 10 randomly selected tufts per plot using a line transect with markings spaced $40 \mathrm{~cm}$ apart. The line transect was extended diagonally across each plot from opposite corners, and inflorescence number and height were determined on fescue tufts closest to each line transect mark. Inflorescence height was measured to the nearest centimeter, and the mean inflorescence number and height from the 10 tufts were used in the analysis. Seed production and viability were determined by collecting all inflorescences from five randomly selected tufts in each treatment. Inflorescences were bagged in the field and brought to the lab, where the total number of seeds produced by each tuft was determined. The mean seed production value of the five tufts collected from each plot was used in the analysis. Seed viability was determined by taking five 100-seed subsamples from the total number of seeds collected from each tuft. Seeds were soaked in water in petri dishes to expose the large embryo within the seed, and the total number of seeds with embryos was determined. Seeds with visible embryos were counted as viable seeds, and values were expressed as the percentage of viable seeds in each subsample. The mean percentage of viable seeds from the five subsamples was used in the analysis. Blueberry stem density was determined in three $0.09-\mathrm{m}^{-2}$ quadrats per plot, with the mean of the three counts used in the analysis. Blueberry stem height and flower bud number per stem were determined on 20 randomly selected stems per plot using the line transect method outlined above. Fescue inflorescence number and height were determined on June 22, 2015 and July 13, 2015, 
respectively. Inflorescences were collected for seed production and seed viability data on August 14, 2015. Blueberry stem density was determined on August 14, 2015. Blueberry stem height and flower bud number per stem were determined on October 16, 2015.

\section{Efficacy of Postemergence Foramsulfuron and Glufosinate Applications on Sheep and Hair} Fescue Seedlings. A greenhouse experiment was conducted to determine the effect of postemergence glufosinate and foramsulfuron applications on sheep and hair fescue seedlings. The experiment had a 4 by 2 factorial design, with herbicide application timing (2, 4, 6, and 8 wk after seedling emergence) and herbicide (glufosinate application at $750 \mathrm{gaiha}^{-1}$, foramsulfuron application at $35 \mathrm{~g} \mathrm{ha}^{-1}$ ) in a completely randomized arrangement with 10 replicates of each treatment combination. Sheep fescue seeds were obtained from a commercial source, and hair fescue seeds were obtained from the Salt Springs site. For each species, a single pre-germinated seed was planted in the center of a $715-\mathrm{cm}^{3}$ plastic cell pack filled with a 1:1:1 (by vol) mixture of sand, potting soil, and peat. Planting dates for each treatment were staggered to ensure that all treatments were sprayed on the same date. An untreated control was planted at the onset of the experiment to provide an estimate of natural damage and/or mortality of fescue plants under the experimental conditions used. Plants were maintained in a greenhouse, under the same conditions outlined for experiment 1 , for the duration of the experiment. Cell packs were kept in plastic greenhouse trays and were re-randomized and fertilized with $50 \mathrm{~mL}$ of $0.12 \%$ 20-20-20 (N-P-K) solution once every $2 \mathrm{wk}$ for the duration of the experiment. Glufosinate and foramsulfuron were applied using a hand-held, $\mathrm{CO}_{2}$-pressurized singlenozzle sprayer outfitted with a Teejet XR 11002 nozzle and calibrated to deliver a water volume of $200 \mathrm{~L} \mathrm{ha}^{-1}$ at a pressure of $207 \mathrm{KPa}$. Data collection included fescue leaf number at the time of herbicide applications, visual estimates of damage at 7, 14, 21, $28,35,42$, and $49 \mathrm{~d}$ after spraying (DAS) using a 0 to 10 integer scale in which 0 meant no plant damage and 10 meant complete plant death, and a value for plant mortality (dead or alive) at 49 DAS.

Statistical Analysis. Testing for normality and variance showed that visual damage ratings in the fescue seedling experiment did not conform to the assumptions for analysis of variance (ANOVA). Mean visual damage ratings for each treatment were determined using PROC MEANS in SAS ${ }^{\circledR}$ Version 9.3 (SAS Institute, Raleigh, NC) and are presented and discussed. Fescue leaf counts in experiment 1 conducted in the greenhouse were analyzed using a repeated measures ANOVA in PROC MIXED in $S A S^{\circledR}$. The effects of glufosinate, foramsulfuron, and the glufosinate by foramsulfuron interaction were modeled as fixed effects, and counting date was modeled as the repeated effect in the analysis. Final sheep fescue biomass in experiment 1 conducted in the greenhouse was analyzed using ANOVA in PROC MIXED in SAS ${ }^{\circledR}$, with the effects of glufosinate, foramsulfuron, and the glufosinate by foramsulfuron interaction modeled as fixed effects. Leaf count data in run 2 of the sheep fescue greenhouse experiment, final biomass data in run 1 of the sheep fescue greenhouse experiment, and leaf count data in the hair fescue greenhouse experiment were squareroot transformed prior to the analysis of variance to meet the assumptions of normality and constant variance, and back-transformed means are presented.

Living and flowering fescue tuft density; flowering fescue tuft inflorescence number, inflorescence height, seed production, and seed viability; and blueberry stem density, stem height, and flower bud density in experiment 1 conducted in the field were analyzed using ANOVA in PROC MIXED in SAS ${ }^{\circledR}$. In the analysis, the effects of glufosinate, foramsulfuron, and the glufosinate by foramsulfuron interaction were modeled as fixed effects, and block was modeled as a random effect. Fescue flowering tuft density, tuft inflorescence number, tuft inflorescence height, and seed production per tuft were log transformed prior to analysis of variance, and seed viability data were square-root transformed, prior to analysis of variance to meet the assumptions of normality and constant variance. The significance of herbicide and herbicide application timing on fescue plant mortality in the second experiment was analyzed using categorical weighted least squares ANOVA in the PROC CATMOD procedure in $\mathrm{SAS}^{\circledR}$. Herbicide and herbicide application timing were considered as categorical variables and modeled as fixed effects in the analysis.

Means for all PROC MIXED-based ANOVA analyses were determined using the LSMEANS statement, and means separation, where necessary, was conducted using Tukey's test at the 0.05 level of 
probability. Differences in mortality rates between treatments in the second experiment were determined by pairwise contrasts in PROC CATMOD.

\section{Results and Discussion}

\section{Effect of Sequential Glufosinate and Foramsulfuron Applications on Sheep and Hair Fescue} Greenhouse Experiment. Significant model effects are presented in Table 1. Although none of the higher-order interactions were significant, for unknown reasons sheep fescue plants in run 1 of the experiment were approximately twice the size of plants in run 2 (see biomass measurements, Table 2). Although trends in results were similar in each run, experimental runs were analyzed separately due to the differences in magnitude of the leaf counts and biomass measurements. Plant size was more consistent in the hair fescue experiment, and there were no significant run by glufosinate by foramsulfuron, run by glufosinate by counting date, run by foramsulfuron by counting date, or run by glufosinate by foramsulfuron by counting date interaction effects on leaf counts (Table 1). Data for hair fescue were therefore combined across experimental runs.

There were significant effects of counting date $(\mathrm{P}<0.0001)$, glufosinate $(\mathrm{P}<0.0001)$, foramsulfuron $(\mathrm{P}<0.0001)$, glufosinate by foramsulfuron
( $\mathrm{P} \leq 0.0040)$, glufosinate by counting date $(\mathrm{P}<$ $0.0001)$, and foramsulfuron by counting date $(\mathrm{P}<0.0001)$ interaction on leaf number in both runs of the sheep fescue experiment, as well as in the combined data for the hair fescue experiment. Sheep fescue leaf number was similar in all treatments prior to initial glufosinate and foramsulfuron applications at 63 DAP in both runs, but decreased significantly in all herbicide treatments relative to the untreated control by 93 DAP (approximately $30 \mathrm{~d}$ after initial herbicide applications) (Table 2). Glufosinate application at 750 and $1,005 \mathrm{~g} \mathrm{ha}^{-1}$, however, provided significantly greater reductions in fescue leaf number relative to foramsulfuron application, and the $405 \mathrm{~g} \mathrm{ha}^{-1}$ application rate of glufosinate, by 93 DAP in each run (Table 2). Results were similar for hair fescue (Table 3). Sheep fescue leaf number for plants treated with glufosinate or foramsulfuron alone at 63 DAP increased significantly between 93 and 123 DAP (Table 2), however, indicating recovery from initial herbicide injury. This is consistent with Smith (1989), who observed rapid recovery of tall fescue following glufosinate applications. Recovery of hair fescue plants from initial herbicide applications was less pronounced, particularly in plants treated with foramsulfuron or 750 and $1,005 \mathrm{~g} \mathrm{ha}^{-1}$ of glufosinate (Table 3). These data indicate potential differences in susceptibility of sheep and hair fescue to glufosinate and foramsulfuron, and additional research should be

Table 1. Test of main and interactive effects of experimental run, glufosinate, foramsulfuron, and counting date on sheep and hair fescue leaf number in a greenhouse pot experiment.

\begin{tabular}{|c|c|c|}
\hline Effects & $\begin{array}{l}\text { Sheep fescue } \\
\text { leaf counts }\end{array}$ & $\begin{array}{l}\text { Hair fescue } \\
\text { leaf counts }\end{array}$ \\
\hline Glufosinate & $* * *$ & $* * *$ \\
\hline Foramsulfuron & $* * *$ & $* * *$ \\
\hline Counting date & $* * *$ & $* * *$ \\
\hline Experimental run by glufosinate & NS & ** \\
\hline Experimental run by foramsulfuron & NS & $* *$ \\
\hline Experimental run by counting date & $*$ & NS \\
\hline Glufosinate by foramsulfuron & ** & $* * *$ \\
\hline Experimental run by glufosinate by foramsulfuron & $* *$ & NS \\
\hline Glufosinate by counting date & $* * *$ & $* * *$ \\
\hline Foramsulfuron by counting date & $* * *$ & $* * *$ \\
\hline Glufosinate by foramsulfuron by counting date & ** & * \\
\hline Experimental run by glufosinate by counting date & NS & NS \\
\hline Experimental run by foramsulfuron by counting date & NS & NS \\
\hline Experimental run by glufosinate by foramsulfuron by counting date & NS & NS \\
\hline
\end{tabular}

Abbreviation: NS, nonsignificant.

${ }^{a}$ Level of significance obtained with PROC MIXED in SAS ${ }^{\circledR}:{ }^{*} \mathrm{P}<0.05$, ** $\mathrm{P}<0.01$, and ${ }^{* * *} \mathrm{P}<0.001$. 
Table 2. Effect of sequential glufosinate and foramsulfuron applications on sheep fescue leaf number and final plant biomass in a greenhouse pot experiment.

\begin{tabular}{|c|c|c|c|c|c|c|c|}
\hline \multirow[b]{2}{*}{ Run } & \multirow[b]{2}{*}{ Glufosinate $^{\mathrm{a}}$} & \multirow[b]{2}{*}{ Foramsulfuron } & \multicolumn{4}{|c|}{ Days after planting } & \multirow[b]{2}{*}{ Final biomass ${ }^{b}$} \\
\hline & & & 63 & 93 & 112 & 123 & \\
\hline & \multicolumn{2}{|c|}{$\overline{\text { g ai ha }^{-1}}$} & . & leav & $\mathrm{ant}^{-1} \mathrm{~b}_{-}$ & & g pot ${ }^{-1}$ \\
\hline & 0 & 35 & $53 \mathrm{~A}(\mathrm{~b})$ & $44 \mathrm{~B}(\mathrm{~b})$ & $71 \mathrm{~B}(\mathrm{a})$ & $66 \mathrm{~B}(\mathrm{ab})$ & $3 \mathrm{~B}$ \\
\hline & 405 & 0 & $53 \mathrm{~A}(\mathrm{~b})$ & $47 \mathrm{~B}(\mathrm{~b})$ & $71 \mathrm{~B}(\mathrm{a})$ & $67 \mathrm{~B}(\mathrm{a})$ & $4 \mathrm{~B}$ \\
\hline & 750 & 35 & 57 A (a) & $16 \mathrm{CD}(\mathrm{b})$ & $19 \mathrm{D}(\mathrm{b})$ & $18 \mathrm{D}(\mathrm{b})$ & $1 \mathrm{C}$ \\
\hline & 1,005 & 0 & 58 A (a) & $20 \mathrm{CD}(\mathrm{c})$ & $39 \mathrm{C}(\mathrm{b})$ & $43 \mathrm{C}(\mathrm{b})$ & $2 \mathrm{BC}$ \\
\hline & 1,005 & 35 & $50 \mathrm{~A} \mathrm{(a)}$ & $8 \mathrm{D}(\mathrm{b})$ & $18 \mathrm{D}(\mathrm{b})$ & $16 \mathrm{D}(\mathrm{b})$ & $1 \mathrm{C}$ \\
\hline \multirow[t]{4}{*}{2} & 0 & 0 & $36 \mathrm{~B}(\mathrm{c})$ & 48 A (b) & $56 \mathrm{~A}(\mathrm{~b})$ & 72 A (a) & $2.5 \mathrm{~A}$ \\
\hline & 0 & 35 & $44 \mathrm{~B}(\mathrm{~b})$ & $35 \mathrm{~B}(\mathrm{~b})$ & $45 \mathrm{~B}(\mathrm{~b})$ & 61 A (a) & $1.5 \mathrm{BC}$ \\
\hline & 1,005 & 0 & $39 \mathrm{~B}(\mathrm{a})$ & $10 \mathrm{D}(\mathrm{c})$ & $23 \mathrm{D}(\mathrm{b})$ & $28 \mathrm{C}(\mathrm{b})$ & $0.6 \mathrm{DE}$ \\
\hline & 1,005 & 35 & $48 \mathrm{AB}(\mathrm{a})$ & $7 \mathrm{D}(\mathrm{b})$ & $6 \mathrm{~F}(\mathrm{~b})$ & $5 \mathrm{E}(\mathrm{b})$ & $0.1 \mathrm{E}$ \\
\hline
\end{tabular}

${ }^{a}$ Initial glufosinate application, as well as the foramsulfuron application made without an initial glufosinate application, were made at $63 \mathrm{~d}$ after planting; subsequent foramsulfuron application was made at $93 \mathrm{~d}$ after planting.

${ }^{\mathrm{b}}$ Leaf count data in run 2 and final biomass data in run 1 were square-root transformed prior to the analysis of variance. Backtransformed means are provided.

${ }^{\mathrm{c}}$ Means within columns followed by the same uppercase letter(s) for each experimental run are not significantly different based on Tukey's means comparison at $\alpha=0.05$.

d Means within rows followed by the same lowercase letter(s) in parentheses are not significantly different based on Tukey's means comparison at $\alpha=0.05$.

conducted to determine if these differences occur in sheep and hair fescue plants that are both collected from wild blueberry fields. Across both species, however, leaf number generally remained consistently lowest in plants treated with 750 or $1,005 \mathrm{~g} \mathrm{ha}^{-1}$ of glufosinate followed by $35 \mathrm{~g} \mathrm{ha}^{-1}$ of foramsulfuron approximately $30 \mathrm{~d}$ later (Tables 2 and 3 ).

There was a significant effect of glufosinate $(P<0.0001)$, foramsulfuron $(P<0.0001)$, and the glufosinate by foramsulfuron interaction (P $\leq$ 0.0286 ) on sheep fescue biomass in run 1 , though there was no significant glufosinate by foramsulfuron interaction effect $(\mathrm{P}=0.4455)$ on biomass in run 2 . In both runs, biomass was lowest in treatments consisting of glufosinate applications of 750 or $1,005 \mathrm{~g} \mathrm{ha}^{-1}$ followed by foramsulfuron (Table 2). These treatments reduced fescue biomass by $82 \%$ to $96 \%$ and $63 \%$ to $93 \%$ relative to the untreated control and foramsulfuron applications alone, respectively (Table 2 ), and provide additional evidence that glufosinate applications of 750 or $1,005 \mathrm{gai} \mathrm{ha}^{-1}$ followed by foramsulfuron have the potential to increase fescue suppression. Sequential herbicide applications also increased tall fescue suppression relative to suppression obtained with individual herbicide applications (Park and Landschoot 2005), and further support the increased effectiveness of sequential herbicide treatments on fescue grasses.

Field Experiment. There were significant site by glufosinate and site by foramsulfuron interaction effects on some of the response variables, but there was no significant effect of the site by glufosinate by foramsulfuron interaction on any of the response variables measured. Based on this, data for these response variables were combined across sites for analysis. There was a significant effect of glufosinate $(P=0.0175)$, but no significant effect of foramsulfuron $(\mathrm{P}=0.1875)$ or glufosinate by foramsulfuron interaction $(\mathrm{P}=0.0864)$ on living fescue tuft density. Living tuft density was generally 
Table 3. Effect of sequential glufosinate and foramsulfuron applications on hair fescue leaf number in a greenhouse pot experiment.

\begin{tabular}{|c|c|c|c|c|}
\hline \multirow[b]{2}{*}{ Glufosinate $^{\mathrm{a}}$} & \multirow[b]{2}{*}{ Foramsulfuron } & \multicolumn{3}{|c|}{ Days after planting } \\
\hline & & 90 & 120 & 150 \\
\hline \multicolumn{2}{|c|}{ g ai ha ${ }^{-1}$} & \multicolumn{3}{|c|}{-leaves plant ${ }^{-1} b_{-}$} \\
\hline 0 & 0 & $149 \mathrm{~A}^{\mathrm{c}}\left(\mathrm{a}^{\mathrm{d}}\right)$ & 157 A (a) & $201 \mathrm{~A}(\mathrm{~b})$ \\
\hline 0 & 35 & 131 A (a) & $120 \mathrm{~A}(\mathrm{a})$ & $88 \mathrm{C}(\mathrm{b})$ \\
\hline 405 & 0 & 128 A (a) & $62 \mathrm{~B}(\mathrm{~b})$ & $133 \mathrm{~B}(\mathrm{a})$ \\
\hline 405 & 35 & 136 A (a) & $60 \mathrm{~B}(\mathrm{~b})$ & $66 \mathrm{C}(\mathrm{b})$ \\
\hline 750 & 0 & 129 A (a) & $6 \mathrm{D}(\mathrm{c})$ & $32 \mathrm{D}(\mathrm{b})$ \\
\hline 750 & 35 & 149 A (a) & $14 \mathrm{C}(\mathrm{b})$ & $12 \mathrm{E}(\mathrm{b})$ \\
\hline 1,005 & 0 & 139 A (a) & $3 \mathrm{D}(\mathrm{c})$ & $17 \mathrm{E}(\mathrm{b})$ \\
\hline 1,005 & 35 & 145 A (a) & $4 \mathrm{D}(\mathrm{b})$ & $1 \mathrm{~F}(\mathrm{~b})$ \\
\hline
\end{tabular}

${ }^{\mathrm{a}}$ Initial glufosinate applications, as well as the foramsulfuron application made without an initial glufosinate application, were made at $90 \mathrm{~d}$ after planting; subsequent foramsulfuron application was made at $120 \mathrm{~d}$ after planting.

${ }^{b}$ Leaf count data were square-root transformed prior to analysis of variance. Back-transformed means are provided.

${ }^{c}$ Means within columns followed by the same uppercase letter(s) are not significantly different based on Tukey's means comparison at $\alpha=0.05$.

${ }^{\mathrm{d}}$ Means within rows followed by the same lowercase letter(s) in parentheses are not significantly different based on Tukey's means comparison at $\alpha=0.05$.

lowest in the foramsulfuron treatment (Table 4), though no treatments reduced density significantly relative to the untreated control. This was not unexpected, however, given the size of established fescue tufts under field conditions and the results of the greenhouse experiment. Fescue flowering tuft density was not affected significantly by glufosinate $(P=0.0591)$, but there was a significant effect of foramsulfuron $(\mathrm{P}=0.0190)$ and the glufosinate by foramsulfuron interaction $(\mathrm{P}=0.0166)$ on this response, likely due to the reduction in flower tuft density in the foramsulfuron treatment relative to the $405 \mathrm{~g} \mathrm{ha}^{-1}$ glufosinate treatment (Table 4). Similar to living tuft density, however, none of the herbicide treatments reduced flowering tuft density relative to the untreated control (Table 4), and results suggest

Table 4. Effect of glufosinate and foramsulfuron applications on hair fescue living tuft density, flowering tuft density, tuft inflorescence number, tuft inflorescence height, and seed production per tuft at commercial wild blueberry fields at Salt Springs and Sherbrooke, Nova Scotia, Canada, and seed viability at Salt Springs, Nova Scotia, Canada.

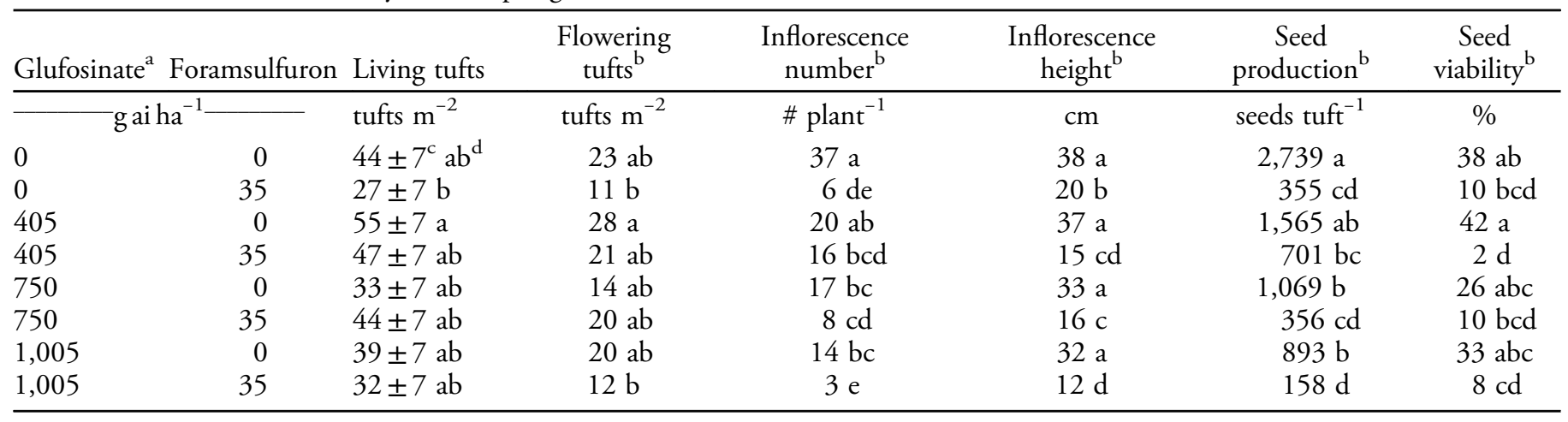

${ }^{a}$ Initial glufosinate applications, as well as the foramsulfuron application made without an initial glufosinate application, were made on May 18, 2015; subsequent foramsulfuron application was made on June 4, 2015.

${ }^{\mathrm{b}}$ Fescue flowering tuft density, tuft inflorescence number, tuft inflorescence height, and seed production per tuft were log transformed prior to analysis of variance. Seed viability data were square-root transformed prior to analysis of variance. Back-transformed means are provided.

${ }^{c}$ Values expressed as mean \pm 1 standard error.

${ }^{\mathrm{d}}$ Means within columns followed by the same letter(s) are not significantly different based on Tukey's means comparison at $\alpha=0.05$. 
that the delay in foramsulfuron applications associated with the sequential treatments used in this experiment reduced suppression of fescues with foramsulfuron under field conditions. Spring glufosinate applications may need to be applied earlier than the timing used in this study to be effective, and autumn applications after pruning should be evaluated as an alternative application timing for glufosinate.

There was a significant effect of glufosinate $(\mathrm{P}<0.0001)$, foramsulfuron $(\mathrm{P}<0.0001)$, and the glufosinate by foramsulfuron interaction $(\mathrm{P} \leq 0.0071)$ on fescue tuft inflorescence number, inflorescence height, and seed production, but trends were generally similar to those observed with living and flowering fescue tuft density. Inflorescence number, much like flowering tuft density, was lowest in the foramsulfuron and the glufosinate at $1,005 \mathrm{~g} \mathrm{ha}^{-1}$ followed by foramsulfuron treatments (Table 4), again indicating that delayed foramsulfuron applications in the sequential treatments reduced fescue suppression at the lower glufosinate application rates. This was most likely due to rapid phenological development of established fescue tufts in early spring, as panicles were visible on flowering fescue plants by late May and early June. Spring glufosinate applications did not suppress tufts enough to prevent flowering (Table 4), and foramsulfuron applications in the sequential treatments were therefore made to fescue plants at later stages of development relative to those plants treated with the foramsulfuron application made on May 18, 2015. It should be noted, however, that all glufosinate application rates, particularly 750 and $1,005 \mathrm{~g} \mathrm{ha}^{-1}$, reduced fescue tuft inflorescence number relative to the untreated control (Table 4). Fescue tufts treated with glufosinate, therefore, did not recover and reach similar levels of growth as tufts in the untreated control, and spring burndown applications of glufosinate provided suppression of fescues without additional herbicide applications. Inflorescence height was lowest in all sequential glufosinate and foramsulfuron treatments, particularly at the glufosinate application rate of $1,005 \mathrm{~g} \mathrm{ha}^{-1}$, indicating that there may be some additional suppressive effect of sequential applications of these herbicides if appropriate timings and use patterns can be determined.

Foramsulfuron reduced seed production per tuft by $87 \%$ relative to the untreated control (Table 4 ). Seed production was similar in tufts treated with foramsulfuron alone and tufts treated with glufosinate at $750 \mathrm{gaiha}^{-1}$ followed by foramsulfuron, but there was a trend towards fewer seeds produced by tufts treated with glufosinate at $1,005 \mathrm{~g} \mathrm{ha}^{-1}$ followed by foramsulfuron (Table 4). Maximum single-season glufosinate application rate in wild blueberry, however, is currently $750 \mathrm{~g} \mathrm{ha}^{-1}$, though applications of $750 \mathrm{~g} \mathrm{ha}^{-1}$ in both autumn, and in the subsequent spring, are permissible under the current registration ( $\mathrm{G}$ Kempton, Bayer CropScience, personal communication). Further research should therefore be conducted before dismissing the potential suppressive effects of sequential applications of these herbicides on fescues and other perennial grasses under field conditions. It should also be noted that glufosinate applications of 405, 750, and $1,005 \mathrm{~g} \mathrm{ha}^{-1}$ reduced seed production per tuft by $43 \%, 60 \%$, and $68 \%$, respectively, relative to the untreated control (Table 4), further confirming the suppressive effects of burndown glufosinate applications on fescues in wild blueberry.

In addition to reductions in total seed production, applications of foramsulfuron, and to some extent glufosinate, reduced fescue seed viability relative to plants in the non-treated control plots (Table 4). Unfortunately, these data were available for the Salt Springs site only, as seed samples from Sherbrooke were accidentally disposed of following initial seed counts. Despite this limitation, these data provide evidence that foramsulfuron reduces both seed production and seed viability in treated fescue plants. Seed viability of other grasses has been reduced with the symplastic herbicide glyphosate (Nurse et al. 2015; Steadman et al. 2006), and our results suggest that sulfonylurea herbicides have a similar effect on sensitive species. Growers can therefore likely expect significant reductions in both total and viable fescue seed production following foramsulfuron applications. It is unclear why the sequential application of glufosinate at $405 \mathrm{~g} \mathrm{ha}^{-1}$ followed by foramsulfuron had the lowest seed viability, though it is possible that reduced damage from the lower glufosinate application rate increased foliar interception and uptake of the subsequent foramsulfuron application.

There was no significant site by glufosinate $(\mathrm{P} \leq 0.5606)$, site by foramsulfuron $(\mathrm{P} \leq 0.9716)$, or site by glufosinate by foramsulfuron $(\mathrm{P} \leq 0.6988)$ interaction effect on blueberry stem density, blueberry stem height, or blueberry flower buds per stem. Data were therefore combined across sites for 
analysis. There was no significant effect of glufosinate $(\mathrm{P} \leq 0.7020)$, foramsulfuron $(\mathrm{P} \leq 0.3328)$, or the glufosinate by foramsulfuron interaction $(\mathrm{P} \leq 0.6421)$ on blueberry stem density, stem height, or flower buds per stem, which averaged $483 \pm 37$ stems $\mathrm{m}^{-2}, 13 \pm 0.3 \mathrm{~cm}$, and $4 \pm 0.2$ buds per stem, respectively. Glufosinate and foramsulfuron did not reduce blueberry stem density, stem height, or flower buds per stem, but the data also suggest that suppression of fescues does not increase yield potential of wild blueberry fields. Initial studies with hexazinone and other preemergence herbicides found large increases in blueberry stem density and flower buds per stem following weed control (Jensen 1986; Yarborough et al. 1986), but lack of blueberry yield potential and yield response to weed control is not uncommon in small plot trials conducted since the widespread adoption of hexazinone and other herbicides (Boyd et al. 2014; Boyd and White 2010; Kennedy et al. 2010). Increases in parameters such as blueberry stem density and flower buds per stem can also take several years to become evident following initiation of weed control treatments (Eaton 1994). Growers report decreased yields and difficulty harvesting fields with heavy fescue infestations, and there is evidence that perennial grasses respond favorably to fertility inputs in wild blueberry (Boyd et al. 2014). Fescues, as well as other perennial grasses, therefore need to be managed despite lack of an immediate increase in yield potential, and our results provide important data on efficacy and crop safety of glufosinate and foramsulfuron in wild blueberry.

Efficacy of Postemergence Foramsulfuron and Glufosinate Applications on Sheep and Hair Fescue Seedlings. Foramsulfuron injury occurred slowly, but greater than $70 \%$ damage was observed in all treated plants by 49 DAS (Table 5). Sheep fescue mortality, however, decreased significantly at later application timings, with low or no mortality

Table 5. Visual damage ratings and mortality of individual sheep and hair fescue plants treated with foramsulfuron or glufosinate at 2, 4,6 , and 8 weeks of age in a greenhouse pot experiment.

\begin{tabular}{|c|c|c|c|c|c|}
\hline Species & Herbicide & Application timing & Leaf \# at application & Visual injury at $49 \mathrm{DAS}^{\mathrm{a}}$ & Mortality \\
\hline & & $\mathrm{WAE}^{\mathrm{b}}$ & $\#$ plant $^{-1}$ & & $\%$ \\
\hline \multirow[t]{6}{*}{ Sheep fescue } & Non-treated control & $-d$ & - & $0 \pm 0$ & 0 \\
\hline & & 4 & $12 \pm 1$ & $9 \pm 0.2$ & $45 \mathrm{~b}$ \\
\hline & & 6 & $32 \pm 2$ & $8 \pm 0.3$ & $10 \mathrm{c}$ \\
\hline & & 8 & $101 \pm 6$ & $8 \pm 0.3$ & $0 \mathrm{c}$ \\
\hline & & 6 & $36 \pm 3$ & $10 \pm 0$ & $100 \mathrm{a}$ \\
\hline & & 8 & $105 \pm 8$ & $10 \pm 0$ & $100 \mathrm{a}$ \\
\hline \multirow[t]{5}{*}{ Hair fescue } & Non-treated control & - & - & $2 \pm 1$ & 0 \\
\hline & Foramsulfuron & 2 & $3 \pm 0.1$ & $7 \pm 1$ & $45 \mathrm{~b}$ \\
\hline & & 4 & $6 \pm 0.3$ & $5 \pm 1$ & $25 \mathrm{~b}$ \\
\hline & & 6 & $22 \pm 3$ & $10 \pm 0$ & $100 \mathrm{a}$ \\
\hline & & 8 & $43 \pm 4$ & $10 \pm 0$ & $100 \mathrm{a}$ \\
\hline
\end{tabular}

\footnotetext{
${ }^{\mathrm{a}}$ Visual estimates of damage were conducted using a 0 to 10 integer scale, where 0 meant no damage and 10 meant complete plant death. DAS, days after spraying.

${ }^{\mathrm{b}}$ WAE, weeks after emergence.

${ }^{\mathrm{c}}$ Foramsulfuron application rate of $35 \mathrm{~g}$ ai ha $^{-1}$; glufosinate application rate of $750 \mathrm{~g} \mathrm{ai} \mathrm{ha}^{-1}$.

${ }^{\mathrm{d}}$ Untreated plants were grown for the duration of the experiment and assessed for mortality at the conclusion of the experiment. Leaf counts were not taken on control plants prior to herbicide applications.

e Values represent the mean \pm 1 standard error.

${ }^{\mathrm{f}}$ Means followed by the same letter do not differ significantly according to a contrast analysis conducted in PROC CATMOD of the $\mathrm{SAS}^{\circledR}$ system for Windows.
} 
in plants treated at 4, 6, and $8 \mathrm{wk}$ after emergence (Table 5). In contrast, foramsulfuron injury, and resulting plant mortality, were generally consistent across application timings for hair fescue (Table 5). These data indicate potential variation in foramsulfuron efficacy across fescue species in wild blueberry fields, and are consistent with the variation in response to foramsulfuron found in the greenhouse experiments described above. The extent, and significance, of this variation under field conditions, however, is unclear. Nevertheless, these results indicate a narrow window for controlling fescue seedlings with foramsulfuron in wild blueberry, and suggest that growers should continue to expect suppression of these grasses with foramsulfuron rather than complete control.

Glufosinate injury occurred rapidly in all treated sheep fescue plants (data not shown), and all plants had died by 49 DAS (Table 5). Necrosis occurred more slowly in hair fescue (data not shown), though the majority of plants died by 49 DAS (Table 5). Glufosinate controls some annual grass seedlings (Tharp et al. 1999), though growth stage affects herbicide efficacy on some species (Lanie et al. 1994). To the best of our knowledge, little research has been conducted on glufosinate efficacy on perennial grass seedlings, and our results suggest that this herbicide may play an important role in managing seedlings of perennial grasses, such as Festuca, in wild blueberry fields. Preliminary data suggest that fescue seedling recruitment occurs in both spring and fall in wild blueberry fields (White, unpublished data), indicating that spring and fall burndown applications of glufosinate may be effective at reducing fescue seedling recruitment if seedlings are emerged at the time of application. It should be stressed, however, that mortality data in this experiment are based on exposure of single plants to glufosinate, and similar levels of mortality are unlikely if seedlings are present at high densities under field conditions. For example, most of the fescue plants treated with glufosinate in the pot experiment survived (Tables 2 and 3), though leaf number was significantly reduced. Efficacy of glufosinate on fescue seedlings, as well as potential impacts of this herbicide on seedling recruitment, should therefore be investigated under field conditions before recommendations for fescue seedling management are made.

Sequential applications of glufosinate and foramsulfuron increased suppression of fescues relative to applications of foramsulfuron alone under greenhouse conditions. Applications of glufosinate at 750 or $1,005 \mathrm{~g} \mathrm{ha}^{-1}$ followed by foramsulfuron reduced fescue tuft leaf number and biomass by $72 \%$ to $76 \%$ and $57 \%$ to $63 \%$, respectively, relative to foramsulfuron applied alone. Results were less consistent under field conditions. Sequential applications of glufosinate and foramsulfuron reduced fescue tuft inflorescence number, inflorescence height, and seed production per tuft in the field, but only at glufosinate application rates of $1,005 \mathrm{~g} \mathrm{ha}^{-1}$. Sequential applications at currently registered rates of glufosinate were less effective, and early applications of foramsulfuron are recommended over sequential herbicide applications under field conditions at this time. Glufosinate suppressed fescues, however, and additional research to evaluate alternative glufosinate application timings should be conducted before ruling out the use of sequential applications of glufosinate and foramsulfuron for management of fescue grasses in wild blueberry. High mortality of individual sheep and hair fescue seedlings occurred following treatment with glufosinate, and this herbicide should be evaluated further for management of fescue seedlings in wild blueberry fields.

\section{Acknowledgements}

Financial support for this research was provided by the Prince Edward Island Wild Blueberry Growers Association, Bluets NB, the Applied Research Subprogram of the Agriculture Research and Innovation Program of Growing Forward 2, and the Prince Edward Island Department of Agriculture and Fisheries. Field sites were provided by Brian McCormack and Jim Wood. The authors also thank Linshan Zhang for assistance with field and laboratory data collection.

\section{Literature Cited}

[AAFC] Agriculture and Agri-Food Canada (2005) Crop Profile for Wild Blueberry in Canada. Ottawa, ON, Canada: Pesticide Risk Reduction Program Pest Management Center. $39 \mathrm{p}$

Anonymous (2015a) Option ${ }^{\circledR} 2.25$ OD Liquid Herbicide product label. Calgary, AB, Canada: Bayer Crop Science

Anonymous (2015b) Wild Blueberry IPM Weed Management Guide, Wild Blueberry Factsheet C, 4, 2.0. http://www2. gnb.ca/content/dam/gnb/Departments/10/pdf/Agriculture/Wild Blueberries-BleuetsSauvages/C420-E.pdf. Accessed March 29, 2016 
Boyd NS, White S (2009) Impact of wild blueberry harvesters on weed seed dispersal within and between fields. Weed Sci 57:541-546

Boyd NS, White S (2010) PRE and POST herbicides for management of goldenrods (Solidago spp.) and black bulrush (Scirpus atrovirens) in wild blueberry. Weed Technol 24:446-452

Boyd NS, White S, Rao K (2014) Fertilizer and fluazifop-P inputs for winter bentgrass (Agrostis hyemalis) infested lowbush blueberry fields. Weed Technol 28:527-534

Cronquist A, Holmgren AH, Holmgren NH, Reveal JL, Holmgren PK (1977) Intermountain Flora. New York: Columbia University Press (The New York Botanical Garden; Volume 6)

Eaton LJ (1994) Long-term effects of herbicide and fertilizers on low bush blueberry growth and production. Can J Plant Sci 74:341-345

Jensen KIN (1985) Weed control in lowbush blueberries in eastern Canada. Acta Hort 165:259-265

Jensen KIN (1986) Response of lowbush blueberry to weed control with atrazine and hexazinone. HortScience 21:1144

Jensen KIN, Kimball ER (1985) Tolerance and residues of hexazinone in lowbush blueberries. Can J Plant Sci 65:223-227

Jensen KIN, Specht EG (2004) Use of two sulfonyl urea herbicides in lowbush blueberry. Small Fruits Rev 3:257-272

Jensen KIN, Yarborough DE (2004) An overview of weed management in the wild lowbush blueberry - past and present. Small Fruits Rev 3:229-255

Kennedy KJ, Boyd NS, Nams VO (2010) Hexazinone and fertilizer impacts on sheep sorrel (Rumex acetosella L.) in wild blueberry. Weed Sci 58:317-322

Lanie AJ, Griffin JL, Vidrine PR, Reynolds DB (1994) Weed control with non-selective herbicides in soybean (Glycine max) stale seedbed culture. Weed Technol 8:159-164

McCully KV, Sampson MG, Watson AK (1991) Weed survey of Nova Scotia lowbush blueberry (Vaccinium angustifolium) fields. Weed Sci 39:180-185

Munro MC, Newell RE, Hill NM (2014) Nova Scotia Plants. Halifax, NS, Canada: Nova Scotia Museum Publications. Pp 1347-1351

Norsworthy JK, Ward SM, Shaw DR, Llewellyn RS, Nichols RL, Webster TM, Bradley KW, Frisvold G, Powles SB, Burgos NR, Witt WW, Barret M (2012) Reducing the risks of herbicide resistance: best management practices and recommendations. Weed Sci 60(SP1): 31-62

Nurse RE, Darbyshire SJ, Simard MJ (2015) Impact of post-anthesis glyphosate on woolly cupgrass seed production, seed weight and seed viability. Can J Plant Sci 95:1193-1197

Park BS, Landschoot PJ (2005) Nonselective herbicides for control of Kentucky bluegrass and tall fescue turf. Int Turfgrass Soc Res J 10:1198-1204

Sampson MG, McCully KV, Sampson DL (1990) Weeds of Eastern Canadian Blueberry Fields. Truro, NS, Canada: Nova Scotia Agricultural College Bookstore. Pp 213-215

Smagula JM, Ismail AA (1981) Effects of fertilizer application, preceded by terbacil, on growth, leaf nutrient concentration, and yield of the lowbush blueberry. Can J Plant Sci 61: 961-964

Smith AE (1989) Herbicides for killing tall fescue (Festuca arundinacea) infected with fescue endophyte (Acremonium coenophialum). Weed Technol 3:485-489

Steadman KJ, Eaton DM, Plummer JA, Ferris DG, Powles SB (2006) Late-season non-selective herbicide application reduces Lolium rigidum seed numbers, seed viability, and seedling fitness. Austral J Agr Res 54:133-141

Tharp BE, Schabenberger O, Kells JJ (1999) Response of annual weed species to glufosinate and glyphosate. Weed Technol 13:542-547

Washburn BE, Barnes TG, Sole SD (1999) No-till establishment of native warm-season grasses in tall fescue fields. Ecol Restor 17:144-149

Yarborough DE (2004) Factors contributing to the increase in productivity in the wild blueberry industry. Small Fruits Rev 3:33-43

Yarborough DE, Hanchar JJ, Skinner SP, Ismail AA (1986) Weed response, yield, and economics of hexazinone and nitrogen use in lowbush blueberry production. Weed Sci 34: $723-729$

Received June 3, 2016, and approved September 2, 2016.

Associate Editor for this paper: Bradley Hanson, University of California, Davis. 